\title{
PENGARUH SUSU KEDELAI DAN LATIHAN FISIK TERPROGRAM TERHADAP DAYA TAHAN OTOT
}

\author{
Kindi Muradi ${ }^{1}$, Sugiarto ${ }^{2}$ \\ Jurusan Ilmu Keolahragaan \\ Fakultas Ilmu Keolahragaan, Universitas Negeri Semarang \\ kindi.muradi2014@gmail.com
}

\begin{abstract}
ABSTRAK
Tujuan penelitian untuk mengetahui pengaruh pemberian susu kedelai dan latihan fisik terprogram terhadap daya tahan otot siswa SSB Cakar Mas Berbah usia 9-12 tahun. Skema pre-post test control group design. Variabel penelitian yaitu: (1) Bebas: pemberian susu kedelai dan latihan fisik terprogram (2) Terikat: daya tahan otot. Populasi berjumlah 16 siswa dengan penarikan sampling yakni "total sampling" menjadi 2 kelompok dengan masing-masing kelompok 8 sampel. Pengambilan data daya tahan otot (wall squat dan sit-up) dilakukan pre-test pada saat sebelum diberi perlakukan dan post-test pada 8 minggu setelah jalannya penelitian. Analisis data menggunakan analisis t-test dengan program SPSS versi 24. Hasil penelitian daya tahan otot siswa menunjukan peningkatan, yaitu dengan rata-rata wall squat pre-test 17.8 , post-test 22.12 dan sit-up pre-test 23.13 , post-test 31,13 pada kelompok eksperimen, sedangkan pada kelompok kontrol wall squat pre-test 16.12, post-test 18.58 dan sit-up pre-test 21.38 , post-test 24.63 . Uji t yang menghasilkan perbandingan daya tahan otot post-test antar kelompok yaitu wall squat $\mathrm{p}=0,01$ dan sit-up $\mathrm{p}=0,00$. Simpulan penelitian ini adalah pemberian susu kedelai secara rutin dan diimbangi dengan latihan fisik terpogram akan meningkatkan daya tahan otot siswa, saran akan terlihat hasil yang lebih signifikan jika melakukan penelitian dengan waktu yang lebih lama.
\end{abstract}

Kata Kunci: Kebugaran Jasmani, Protein, Bola Besar, Usia Dini

\begin{abstract}
The aim of research to determine the effect of soy milk and programmed physical exercise towards muscle endurance student in SSB Cakar Mas Berbah aged 9-12 years. Scheme pre-posttest control group design. The research variables are: (1) Free: provision of soy milk and programmed physical exercise (2) Bound: muscular endurance. The population of 16 students with the withdrawal of sampling the "total sampling" into two groups with each group of 8 samples. Then the data retrieval muscular endurance (wall squat and sit-ups) carried out during the pre-test before being given treatment and post-test at 8 weeks after the course of the study. Analyzed using t-test with SPSS version 24. The results of the study on student muscular endurance showed an increase, with an average of wall squat 17.8 pre-tests, post-test 22.12 and sit up 23.13 pre-test, post-test 31.13 in the group treatment, while the control group wall squat 16.12 pre-test, post-test 18.58 and sit up 21.38 pre-test, post-test 24.63. T-test that results in muscle endurance comparison post-test between groups, $p=0,01$ wall squat and sit-up $p=0.00$. Conclusions this research was the soy milk regularly and balanced with programmed physical exercise will increase muscle endurance students, suggestions will look significantly better results when doing research with a longer period of time.
\end{abstract}

Keywords: Physical Fitness, Protein, Big Ball, Early Age

Dipublikasikan Oleh :

UPT Publikasi dan Pengelolaan Jurnal

Universitas Islam Kalimantan Muhammad Arsyad Al-Banjari Banjarmasin 


\section{PENDAHULUAN}

Olahraga merupakan aktivitas yang populer dan banyak dilakukan oleh kalangan anak-anak, ramaja, dewasa hingga orang tua. Menurut Abdulaziz, Dharmawan, \& Putri (2016), ada empat tujuan manusia melakukan kegiatan olahraga yaitu: 1) rekreasi yaitu manusia melakukan olahraga hanya untuk mengisi waktu senggang dan melakukan dengan gembira, santai tidak formal, baik tempat sarana maupun peraturan yang digunakan. 2) pendidikan artinya olahraga yang dilakukan formal tujuannya untuk mencapai sasaran pendidikan nasional melalui kegiatan olahraga yang telah disusun melalui kurikulum tertentu. 3) mencapai tingkat kesegaran jasmani. 4) mencapai sasaran prestasi tertentu.

Salah satu olahraga yang digemari dan prestisius dikalangan masyarakat Indonesia yaitu, sepak bola. Menurut (Laksmi, 2011 dalam Bryantara, 2016), sepak bola merupakan suatu jenis olahraga yang dapat disetarakan dengan tingkat kebutuhan energi yang sama dengan pekerja berat. Hal ini disebabkan karena sepak bola termasuk jenis olahraga yang membutuhkan koordinasi gerak cepat dalam kurun waktu yang lama. Menurut Chan, et al. (2016), kebugaran jasmani menjadi salah satu elemen paling penting yang mempengaruhi kinerja tim sepak bola karena permintaan fisik yang tinggi dalam situasi pertandingan nyata.

Kebugaran jasmani menjadi salah satu unsur penting dalam peningkatan kualitas performa atlet untuk mencapai prestasi yang diharapkan. Semakin baik kebugaran jasmaninya, maka akan semakin kecil juga kelelahan yang nanti akan dirasakan, baik dalam setiap latihan maupun dalam pertandingan (Fauzan \& Dirgantoro, 2020). Menurut (American College of Sport Medicine, 2014), kebugaran fisik terbagi atas dua komponen utama yakni komponen kebugaran fisik yang berkaitan dengan kesehatan, terdiri dari, daya tahan kardiorespirasi (cardiorespiratory endurance), komposisi tubuh (body composition), kekuatan otot (muscular strenght), daya tahan otot (muscular endurance), dan kelenturan (flexibility), sedangkan komponen kebugaran fisik yang berkaitan dengan keterampilan terdiri dari, kelincahan (agility), koordinasi (coordination), keseimbangan (balance), daya ledak (power), waktu reaksi (reaction time), kecepatan (speed).

Salah satu aspek kebugaran jasmani yang mempengaruhi pemain sepak bola adalah daya tahan otot. Daya tahan otot adalah kemampuan otot atau sekelompok otot untuk mempertahankan kontraksi berulang terhadap resistensi untuk jangka waktu yang lama. Ini adalah salah satu komponen kebugaran otot, bersama dengan kekuatan otot dan daya ledak (Quinn, 2018). Daya tahan otot erat kaitannya dengan kebugaran jasmani seseorang. Pada permainan sepak bola, daya tahan otot diperlukan untuk menghindari kelelahan berlebihan sehingga atlet mampu menjalani waktu pertandingan yang lebih lama. Daya tahan otot yang baik dapat dicapai dengan beberapa cara, salah satunya yaitu dengan meningkatkan aktivitas fisik dan melakukan latihan fisik atau olahraga terprogram secara baik, benar, terukur dan teratur.

Faktor lain yang mempengaruhi daya tahan otot yaitu asupan nutrisi. Salah satu kebutuhan makro nutrisi yang paling penting adalah protein. Berdasarkan sumbernya, protein dibagi menjadi 2, yaitu protein hewani dan protein nabati. Bahan makanan yang dijadikan untuk pemenuhan protein harian sebagai sumber protein nabati menurut (Almatsier, 2004), salah satunya adalah semua jenis kacang-kacangan dan hasil olahannya, seperti tempe, tahu, dan pindakas. Kedelai merupakan tanaman jenis kacang-kacangan yang keberadaannya cukup banyak di Indonesia. Kacang kedelai ini juga menjadi salah satu jenis sumber protein nabati yang mempunyai mutu atau nilai biologi tertinggi.

Protein berfungsi untuk meningkatkan performa aerobik (daya tahan) otot lengan dan kaki dengan meningkatkan massa otot tubuh. Protein yang membantu dalam proses terbentuknya energi dan meningkatnya massa otot adalah karnitin. Karnitin disintesis dari asam amino esensial yaitu lisin dan metionin. Di dalam mitokondria, karnitin berperan untuk menghasilkan energi dan memiliki peran dalam peningkatan daya tahan otot (Syafrizar \& Welis, 2009). Ketika menjalani program latihan, mengkonsumsi makanan atau minuman yang mengandung protein akan meningkatkan proses pembakaran lemak membatasi penyerapan karbohidrat dalam tubuh, dengan mengkonsumsi beberapa jenis bahan makanan yang mengandung protein seperti kacang-kangan dan beberapa makanan lainnya akan menggantikan komponen glukosa yang masuk ke tubuh dengan komponen asam amino yang nantinya akan sangat di manfaatkan oleh otot untuk menambah massa otot dan meningkatkan kekuatan otot yang juga akan berdampak pada daya tahan otot (Andrie, 2015 dalam Amrulloh. A.A, 2017).

Susu kedelai merupakan salah satu minuman olahraga yang baik dikonsumsi, terutama selama pemulihan dari latihan ketahanan dan daya tahan olahraga. Berdasarkan penelitian terdahulu, susu kedelai sepertinya menjadi minuman efektif setelah latihan, yang dapat menghasilkan perubahan akut yang menguntungkan dalam metabolisme protein. Konsumsi susu kedelai akut meningkatkan sintesis protein otot, sehingga menyebabkan keseimbangan protein otot membaik. Ketika konsumsi susu kedelai setelah latihan dikombinasikan dengan latihan ketahanan, peningkatan yang lebih besar dalam hipertrofi otot telah diamati. Meskipun penelitian dengan susu kedelai terbatas, ada beberapa bukti yang menunjukkan bahwa susu kedelai dapat menjadi minuman pasca latihan yang efektif untuk kegiatan ketahanan (Roy, 2008).

\section{Dipublikasikan Oleh :}

UPT Publikasi dan Pengelolaan Jurnal

Universitas Islam Kalimantan Muhammad Arsyad Al-Banjari Banjarmasin 
Penelitian terdahulu yang dilakukan oleh Romadhon, Mukarromah, \& Setiowati (2019), terkait pemberian susu kedelai terhadap kekuatan otot pada 36 member di Fitness Center Hotel Pandanaran Semarang menyatakan bahwa terdapat pengaruh pemberian susu kedelai pada kekuatan otot lengan, otot kaki dan otot punggung. Pada penelitian tersebut terdapat 2 kelompok, yaitu kelompok kontrol dan kelompok perlakuan. Responden pada kelompok kontrol diberikan program latihan + air putih $350 \mathrm{ml}$, sedangkan kelompok perlakuan diberikan susu kedelai sebannyak $600 \mathrm{ml}+$ program latihan yang dapat meningkatkan kekuatan otot. Hasil dari penelitian menunjukkan ada perbedaan yang signifikan antara kelompok perlakuan dan kelompok kontrol, meskipun hasil uji independent sample t-test pada masing-masing kelompok menunjukkan hasil perbedaan yang tidak signifikan $\mathrm{p}=0,250 \mathrm{p}=0,221$ dan $\mathrm{p}=0,601(\mathrm{p}>0,05)$. Berdasarkan uraian di atas peneliti tertarik untuk mengetahui pengaruh susu kedelai dan latihan fisik terprogram terhadap daya tahan otot siswa SSB Cakar Mas Berbah U 9-12 tahun.

METODE

Jenis Metode penelitian kuantitatif dengan rancangan skema pre-post test control group design. Variabel penelitian yaitu: (1) Variabel bebas: pemberian susu kedelai dan latihan fisik terprogram (2) Variabel terikat : daya tahan otot siswa SSB Cakar Mas Berbah usia 9-12 tahun. Populasi berjumlah 16 siswa dengan penarikan sampling yakni "total sampling" dengan menggunakan 16 siswa dibagi menjadi 2 kelompok dengan masingmasing kelompok 6 sampel. Kemudian pengambilan data dilakukan pretest pada saat sebelum diberi perlakukan dan post test pada 8 minggu setelah jalannya penelitian.

Penelitian dilakukan di Sekolah Sepak Bola (SSB) Cakar Mas Berbah, yaitu berupa pemberian perlakuan dengan pemberian susu kedelai dan latihan fisik terprogram selama 8 minggu pada kelompok eksperimen dengan jumlah $400 \mathrm{ml}$ dan air mineral yang diberi pada kelompok kontrol dalam jumlah yang sama. Latihan untuk siswa dilakukan 3 kali dalam 1 minggu yang dilakukan setiap hari selasa, kamis, dan minggu. Pengambilan data dilakukan pada pretest yaitu wall squat dan sit up pada minggu pertama sebelum dilakukan perlakuan pemberian asupan dan latihan fisik terprogram dan post test dilakukan pada minggu ke 8 . Analisis data dalam penelitian ini menggunakan spss 24.

\section{HASIL DAN PEMBAHASAN}

1. Deskripsi Hasil

1.1 Karakteristik Sampel

Penelitian dengan sampel 16 anak ini tentunya memiliki karakteristik yang berbeda dari usia, tinggi badan, berat badan, IMT, dan daya tahan otot awal mereka. Dalam penelitian ini, peneliti menganggap semua sampel dengan keadaan awal yang sama, sehingga peneliti menguji dengan $t$ test yang nantinya akan menunjukan bahwa antara kelompok eksperimen dan kelompok kontrol mempunyai keadaan fisik yang sama. Berikut adalah deskripsi karakteristik sampel penelitian antara kelompok eksperimen dan kelompok kontrol:

Tabel 1. Deskripsi Karakteristik Sampel

\begin{tabular}{lccc}
\hline \multicolumn{1}{c}{ Variabel } & \multicolumn{3}{c}{ Kelompok } \\
\cline { 2 - 4 } \multicolumn{1}{c}{$\mathbf{n}=\mathbf{1 6}$} & $\begin{array}{c}\text { Rerata } \pm \text { SD } \\
\text { Eksperimen }\end{array}$ & $\begin{array}{c}\text { Rerata } \pm \text { SD } \\
\text { Kontrol }\end{array}$ & P \\
\hline Usia (tahun) & $10,50 \pm 1,19$ & $10,50 \pm 1,19$ & 1,00 \\
TB $(\mathrm{cm})$ & $135,63 \pm 0,75$ & $135,63 \pm 0,66$ & 0,76 \\
BB $(\mathrm{m})$ & $36,75 \pm 7,99$ & $38,13 \pm 11,23$ & 0,29 \\
IMT $\left(\mathrm{kg} / \mathrm{m}^{2}\right)$ & $19,77 \pm 2,22$ & $20,42 \pm 4,31$ & 0,13 \\
Daya Tahan & & & \\
Wall Squat Test (detik) & $17,80 \pm 5,91$ & $16,12 \pm 3,29$ & 0,11 \\
Sit-up Test (kali/menit) & $23,13 \pm 7,27$ & $21,3 \pm 6,18$ & 0,7 \\
\hline Sumbr
\end{tabular}

Sumber : Data primer yang diolah, 2021

Tabel menunjukkan rata-rata karakteristik sampel antara kelompok eksperimen dan kelompok kontrol. Hasil tersebut dikonsultasikan dengan tingkat signifikan $\alpha 5 \%(0,05)$, dan pada masing-masing hasil $\mathrm{p}>$ 0,05 sehingga dalam penelitian ini peneliti menganggap semua sampel mempunyai keadaan fisik yang sama. Peneliti membandingkan dengan uji t, yaitu uji pembanding antara kelompok eksperimen dan 
kelompok kontrol, sehingga menghasilkan rerata antara usia, tinggi badan, berat badan, IMT, daya tahan wall squat, dan daya tahan sit up yang sama antara kelompok eksperimen dan kelompok kontrol.

\subsection{Hasil Pola Konsumsi Gizi}

Penelitian yang dilakukan dengan pemberian asupan protein yang ada dalam susu kedelai untuk meningkatkan daya tahan otot siswa SSB Cakar Mas Berbah tentunya harus menganalisis asupan protein lain selain dari susu kedelai yang diberikan oleh peneliti untuk menghitung jumlah protein yang diasup di luar jalannya penelitian, sehingga peneliti menganjurkan para responden menulis menu makanan 24 jam dalam lembar foodrecall, sehingga peneliti dapat menghitung dengan mudah asupan protein yang telah dikonsumsi oleh responden dengan akurat. Berikut adalah tabel yang akan disajikan mengenai rata-rata asupan gizi yang dikonsumsi oleh responden:

Tabel 2. Hasil Pola Komsumsi Gizi Siswa SSB Cakar Mas Berbah

\begin{tabular}{lccc}
\hline & \multicolumn{2}{c}{ Rata-rata } & $\mathrm{p}$ \\
\cline { 2 - 3 } & Kontrol & Eksperimen & \\
\hline Minggu I & 1160 & 1161 & 0,97 \\
Energi (kal) & 151 & 156 & 0,08 \\
Karbohidrat (kal) & 44 & 50 & 0,07 \\
Protein (g/hari) & 44 & 43 & 0,67 \\
Lemak (g/hari) & & & \\
\hline Minggu VIII & 1166 & 1213 & 0,19 \\
Energi (kal) & 156 & 162 & 0,29 \\
Karbohidrat (kal) & 46 & 56 & 0,00 \\
Protein (g/hari) & 40 & 44 & 0,18 \\
Lemak (g/hari) & & & \\
\hline
\end{tabular}

Sumber: Data primer yang diolah, 2021

Tabel hasil konsumsi gizi di atas menunjukkan bahwa adanya peningkatan rata-rata, terutama pada peningkatan protein kelompok eksperimen yang disebabkan oleh pemberian susu kedelai selama 8 minggu. Hasil protein yang di peroleh kelompok eksperimen pada minggu 1 yaitu $51 \mathrm{~g} / \mathrm{hari}$ dan minggu 8 yaitu 56 g/hari, sedangkan pada kelompok kontrol jumlah protein pada minggu 1 yaitu 44 g/hari dan minggu 8 yaitu 46 g/hari. Hal tersebut berarti pemberian susu kedelai efektif untuk meningkatkan jumlah asupan protein untuk meningkatkan daya tahan otot.

\subsection{Hipotesis}

Uji Hipotesis dilakukan untuk mengetahui benar atau tidaknya hipotesis dalam penelitian ini. Hipotesis dalam penelitian ini yaitu:

H0: Susu kedelai dan latihan fisik terprogram tidak mempengaruhi daya tahan otot siswa SSB Cakar Mas Berbah usia 9-12 tahun.

H1: Susu kedelai dan latihan fisik terprogram mempengaruhi daya tahan otot siswa SSB Cakar Mas Berbah usia 9-12 tahun.

\subsubsection{Peningkatan Daya Tahan Otot}

Berikut adalah tabel yang akan disajikan mengenai peningkatan daya tahan otot siswa Sekolah Sepak Bola (SSB) Cakar Mas Berbah yang telah diberi perlakuan yaitu latihan fisik terprogram dan pemberian susu kedelai untuk kelompok perlakuan dan air mineral pada kelompok kontrol.

Tabel 3. Perbedaan Daya Tahan Otot pada Kelompok Eksperimen

\begin{tabular}{lccc}
\hline \multirow{2}{*}{ Variabel } & \multicolumn{2}{c}{ Rata-rata } & p \\
\cline { 2 - 3 } & Pre Test & Post Test & 0,00 \\
\hline Wall Squat (detik) & 17,8 & 22,12 & 0,00 \\
Sit Up (kali/menit) & 23,13 & 31,13 & \\
\hline
\end{tabular}

Dipublikasikan Oleh :

UPT Publikasi dan Pengelolaan Jurnal

Universitas Islam Kalimantan Muhammad Arsyad Al-Banjari Banjarmasin 
Sumber : Data primer yang diolah, 2021

Perbandingan daya tahan otot kelompok eksperimen antara pretest dan posttest menunjukan pada wall squat $\mathrm{p}=0,00$ dan pada sit up $\mathrm{p}=0,00$. Hasil tersebut dikonsultasikan dengan tingkat signifikan $\alpha$ $5 \%(0,05)$. Karena dari masing-masing hasil di tabel atas menunjukan $<0,05$ maka dapat disimpulkan daya tahan otot dari kelompok eksperimen masing-masing pretest dan posttest berdistribusi ada perbedaan.

Tabel 4. Perbedaan Daya Tahan Otot pada Kelompok Kontrol

\begin{tabular}{lccc}
\hline \multirow{2}{*}{ Variabel } & \multicolumn{2}{c}{ Rata-rata } & P \\
\cline { 2 - 3 } & Pre Test & Post Test & \\
\hline Wall Squat (detik) & 16,12 & 18,58 & 0,00 \\
Sit Up (kali/menit) & 21,38 & 24,63 & 0,00 \\
\hline
\end{tabular}

Sumber : Data primer yang diolah, 2021

Perbandingan daya tahan otot yang telah disajikan pada tabel di atas menunjukkan bahwa nilai $\mathrm{p}$ pada kelompok kontrol yaitu $\mathrm{p}=0,00$ pada wall squat dan $\mathrm{p}=0,00$ pada sit up. Hasil tersebut dikonsultasikan dengan tingkat signifikan $\alpha 5 \%(0,05)$. Karena dari masing-masing hasil di tabel atas menunjukan $<0,05$ maka dapat disimpulkan daya tahan otot dari kelompok kontrol masing-masing pretest dan posttest berdistribusi ada perbedaan, hal tersebut menunjukan bahwa hipotetsis (H1) diterima karena perbedaan yang signifikan.

Pada tabel di atas menunjukkan bahwa peningkatan daya tahan otot pada kelompok eksperimen lebih tinggi dibanding kelompok kontrol, hal tersebut dapat dilihat pada hasil peningkatan daya tahan otot pada kelompok eksperimen yaitu $24,26 \%$ pada tes wall squat dan $36,01 \%$ pada tes sit up, sedangkan pada kelompok kontrol yaitu $13,39 \%$ pada tes wall squat dan $15,57 \%$ pada tes sit up.

\subsubsection{Perbandingan Daya Tahan Otot}

Hasil dari tes daya tahan otot antara kelompok perlakuan dan kelompok kontrol akan disajikan pada Tabel 1.5 Berikut adalah perbandingan antara kelompok perlakuan dan kelompok kontrol:

Tabel 5. Perbandingan Daya Tahan Otot

\begin{tabular}{lccc}
\hline \multirow{2}{*}{ Variabel } & \multicolumn{2}{c}{ Kelompok } & \multirow{2}{*}{ P } \\
\cline { 2 - 3 } & Eksperimen & Kontrol & \\
\hline Wall Squat (detik) & 4,32 & 2,46 & 0,01 \\
Sit Up (kali/menit) & 8,00 & 3,25 & 0,00 \\
\hline
\end{tabular}

Sumber : Data primer yang diolah, 2021

Dari hasil perbandingan kenaikan daya tahan otot antara kelompok eksperimen dan kelompok kontrol menunjukkan antara kedua kelompok $p=0,02$ pada wall squat dan $p=0,00$ pada sit up dapat dilihat dari hasil pada tes wall squat dan tes sit up menunjukan $\mathrm{p}<0,05$ yang berarti ada perbedaan. Hal tersebut diartikan susu kedelai berpengaruh terhadap daya tahan otot baik sit up maupun daya tahan otot wall squat, dan keduanya sama-sama mengalami peningkatan daya tahan otot yang disebabkan oleh latihan fisik terprogram, tentunya kelompok eksperimen mengalami peningkatan yang lebih tinggi dibanding kelompok kontrol, sehingga dapat disimpulkan bahwa pemberian susu kedelai dan latihn fisik terprogram mempengaruhi daya tahan otot siswa Sekolah Sepak Bola (SSB) Cakar Mas Berbah.

\section{PEMBAHASAN}

Pada penelitian yang dilakukan oleh Deden Saeful. A (2013) menunjukan bahwa pemberian protein yang terkandung dalam susu sapi murni dan susu kedelai untuk meningkatkan massa otot yang tentunya berpengaruh pada recovery otot dan daya tahan otot lebih dapat dilihat hasil peningkatan kelompok dengan susu kedelai dibandingkan kelompok dengan susu sapi murni, hal ini menjadi acuan oleh peneliti bahwa susu kedelai lebih berpengaruh untuk meningkatkan daya tahan otot.

Dipublikasikan Oleh :

UPT Publikasi dan Pengelolaan Jurnal

Universitas Islam Kalimantan Muhammad Arsyad Al-Banjari Banjarmasin 
Selain itu, pada penelitian yang dilakukan oleh Abdul Aziz Al Karimi A. (2017) juga menunjukkan bahwa pemberian susu kedelai terhadap atlet Karate Kota Tegal mampu meningkatkan daya tahan otot secara signifikan. Hal ini ditunjukkan dengan perbandingan peningkatan daya tahan otot atlet, baik perbandingan peningkatan daya tahan otot antar kelompok eksperimen dan kontrol maupun perbandingan daya tahan otot antar kelompok keseluruhan.

Hasil penelitian ini menunjukan bahwa daya tahan otot rata-rata pada kelompok eksperimen pada tes wall squat sebesar $p=0,00$ dan pada sit up sebesar $p=0,00$, sedangkan pada kelompok kontrol $p=0,00$ pada wall squat dan $\mathrm{p}=0,00$ pada sit up. Perbandingan peningkatan daya tahan otot antar kelompok menunjukan bahwa $\mathrm{p}$ $=0,01$ pada wall squat dan $\mathrm{p}=0,00$ pada sit up. Hasil tersebut dikonsultasikan dengan tingkat signifikan $\alpha 5 \%$ $(0,05)$, dapat terlihat masing-masing tes menunjukan $\mathrm{p}<0,05$ sehingga dapat disimpulkan baik dari daya tahan otot wall squat maupun sit up ada perbedaan, dan terlihat data yang signifikan dapat menunjukan perbandingan antara kelompok eksperimen dan kelompok kontrol. Memberikan gambaran bahwa pemberian susu kedelai dan latihan fisik terprogram memberikan pengaruh pada daya tahan otot yang dapat dilihat dalam tabel yang telah disajikan sebelumnya dengan pre-test dan post-test.

Sampel pada kelompok eksperimen diberikan susu kedelai sebanyak $400 \mathrm{ml}$ selama 8 minggu dan aktivitas berupa latihan fisik terprogram yang dilakukan 3 kali dalam 1 minggu diperoleh hasil tes wall squat dan sit up lebih banyak dibanding kelompok kontrol. Rata-rata pada tes daya tahan otot pada tes wall squat yaitu 22,12 detik pada kelompok eksperimen dan 18,58 detik pada kelompok kontrol, sedangkan pada tes sit up yaitu $31,13 \mathrm{kali} /$ menit pada kelompok eksperimen dan 24,63 kali/menit pada kelompok kontrol. Pada dasarnya susu kedelai baik dikonsumsi untuk meningkatkan daya tahan baik itu daya tahan otot maupun imunitas. Pemberian susu kedelai dapat menambah imunoglobulin sehingga pada saat melakukan aktivitas fisik lebih bertahan lama (Fihiruddin, 2013).

Peneliti telah menambahkan tambahan protein setiap hari pada kelompok eksperimen berupa susu kedelai sebanyak $400 \mathrm{ml}$. Susu kedelai yang berasal dari olahan biji kedelai sebesar 66,4 gram tersebut mengandung 10,96 gram protein, sehingga dari rata-rata 50,7 g/hari pada kelompok eksperimen asupan protein responden bertambah dengan 10,96 menjadi 61,66 g/hari, tetapi dalam sajian tabel food recall 24 jam, ada kemungkinan asupan protein dari luar susu kedelai menurun, hasil dari rata-rata asupan protein post test yaitu $50,7 \mathrm{~g} / \mathrm{hari}$, sehingga sudah memenuhi kapasitas anjuran asupan protein untuk melakukan latihan yaitu kurang lebih 10-15\% dari jumlah energi yang dikonsumsi.

Latihan fisik yang diberikan secara serentak dan dengan intensitas yang sama tetapi dengan perlakuan pemberian nutrisi yang berbeda akan menghasilkan daya tahan otot yang berbeda juga, hal ini dikarenakan protein yang terbukti bagus untuk penambahan massa otot dan juga daya tahan otot terkandung dalam susu kedelai dengan jumlah yang banyak, yaitu sebanyak 30,90 gram dalam 100 gram biji kedelai (Budimarwanti, 2007 dalam Amrulloh, 2017).

\section{PENUTUP}

Simpulan dalam penelitian ini adalah pemberian asupan protein yang terkandung dalam susu kedelai dengan takaran $400 \mathrm{ml}$ dan efektif dalam meningkatkan daya tahan terutama daya tahan otot dengan diimbangi latihan fisik terprogram.

Saran yang diberikan dalam penelitian ini adalah (1) Sebagai salah satu alternatif mengkonsumsi susu kedelai sebelum dilakukannya latihan fisik terprogram dapat meningkatkan daya tahan otot, tetapi akan lebih terlihat hasilnya jika melakukan pemberian lebih lama dari waktu yang diberikan pada penelitian ini; (2) Bagi penelitian selanjutnya, hasil dari penelitian ini bisa digunakan sebagai acuan dasar untuk penelitian yang relevan, dengan memperhatikan kelemahan dari penelitin ini.

\section{REFERENSI}

Abdulaziz, M. F., Dharmawan, D. B., \& Putri, T. D. (2016). Motivasi Mahasiswa Terhadap Aktivitas Olahraga Pada Sore Hari di Sekitar Area Taman Sutera Universitas Negeri Semarang. Journal of Physical Education Health and Sport, 113-120.

Almatsier, S. (2004). Prinsip Dasar Ilmu Gizi. Jakarta: PT. Gramedia Pustaka Utama.

American College of Sport Medicine. (2014). ACSM's Health-Related Physical Fitness Assessment (4th ed.). Philadelphia PA: Lippincott Williams \& Wilkins.

Dipublikasikan Oleh :

UPT Publikasi dan Pengelolaan Jurnal

Universitas Islam Kalimantan Muhammad Arsyad Al-Banjari Banjarmasin 
Amrulloh, A. A. (2017). Pengaruh Pemberian Susu Kedelai Terhadap Daya Tahan Otot Atlet Karate Kota Tegal. Skripsi. Fakultas Ilmu Keolahragaan. Universitas Negeri Semarang.

Azhar, D. S. (2013). Perbandingan Pengaruh Susu Sapi Murni Dengan Susu Kedelai Terhadap Peningkatan Massa Otot Pada Latihan Beban. Skripsi. Fakultas Pendidikan Olahraga dan Kesehatan. Universitas Pendidikan Indonesia.

Bryantara, O. F. (2016). Faktor yang Berhubungan Dengan Kebugaran Jasmani (Vo2Maks) Atlet Sepakbola. Jurnal Berkala Epidemiologi, 237-249.

Budimarwati, C. (2007). Komposisi dan Nutrisi Pada Susu Kedelai. Indonesia: FMIPA UNY.

Chan, H. C.-K., Fong, D. T.-P., Lee, J. W.-Y., Yau, Q. K.-C., Yung, P. S.-H., \& Chan, K.-M. (2016). Power and Endurance in Hongkong Professional Football Players. Asia-Pacific Journal of Sport Medicine, 1-5.

Fauzan, L. A., \& Dirgantoro, E. W. (2020). Profil Kebugaran Jasmani Atlet Pencak Silat PPLP Kalimantan Selatan. Riyadhoh Jurnal Pendidikan Olahraga, 3, 80-86.

Fihiruddin. (2013). Pengaruh Pemberian Susu Kedelai Terhadap Respon Antibodi dan Proliferasi Sel Limfosit Pada Mencit Babl/c yang Di Induksi Dengan Vaksin Hepatitis B. Media Bina Ilmiah, 7 No 5.

Romadhon, A., Mukarromah, S. B., \& Setiowati, A. (2019). Pengaruh Pemberian Susu Kedelai Terhadap Kekuatan Otot. Journal of Sport Sciences and Fitness.

Roy, B. D. (2008). Milk : The New Sports Drink? A Review. Journal of the International Society of Sports Nutrition volume, 5,15 .

Syafrizar, \& Welis, W. (2009). Gizi Olahraga. Malang: Wineka Media.

Dipublikasikan Oleh :

UPT Publikasi dan Pengelolaan Jurnal

Universitas Islam Kalimantan Muhammad Arsyad Al-Banjari Banjarmasin 